\title{
Combined Manufacturing Lines feature a new Strategy in Flexible Manufacturing Systems
}

\author{
DiPL.-ING. AYMAN Al KHATEEB \\ DEPARTMENT FOR INDUSTRIAL ENGINEERING \\ UNIVERSITY OF ILMENAU, GERMANY
}

\begin{abstract}
In manufacturing and assembly the buffers are used on the one hand for the decoupling of process steps, on the other hand to avoid the negative effects of failures. The aim is always to reach an efficient work of the equipment with high throughput by good economy.

Factories with identical manufacturing lines producing equal products or workpieces offer the possibility of applying the principle of the buffer network. The configuration of the new model is focussed on the combination of two common identical manufacturing lines which are combined by joint buffers. Initially, this combination entails a reduction of required buffer size which finally results in a reduction of original buffer capacities by half, reduction of space required, reduced effects of failures, economically practicable increase in throughput and thus a reduction in capital expenditure.
\end{abstract}

\section{Zusammenfassung}

In Fertigung und Montage dienen die Puffer einerseits der Entkopplung von Prozessschritten, andererseits der Vorbeugung negativer Wirkungen von Störungen. Ziel ist es stets, einen effizienten Ablauf mit hohem Durchsatz bei guter Wirtschaftlichkeit der Anlagen zu erreichen.

In Fabriken, die mit identischen Fertigungslinien zur Herstellung gleicher Produkte oder Werkstücke ausgerüstet werden, besteht die Möglichkeit, das Prinzip der vernetzten Pufferung anzuwenden. Die Kombination von zwei identischen Fertigungslinien mittels gemeinsam genutzter Puffer steht im Mittelpunkt der Auslegung des neuen Modells. Zunächst führt diese Kombination zur Senkung der erforderlichen Pufferkapazitäten. Die Folge davon sind die Reduzierung der Puffer um die Hälfte der ursprünglichen Kapazitäten, Verkleinerung des Flächenbedarfs, Verminderung von Störungswirkungen, eine wirtschaftlich mögliche Erhöhung des Durchsatzes und schließlich dadurch eine Verringerung der Investitionskosten.

\section{Introduction}

Based on the possibilities of linkages the order of the buffers in the equipment layout is illustrated. This leads to the evaluation of the combined structure. To investigate this structure the analytical method as well as the simulation is applied. The comparison of the structure entails clear results with regard to space required, throughput and failure effects.

Flexible manufacturing systems can be improved by the development of the production principle, (see e.g. [Tuff.1988]). To reduce intermediate storage times between working stations, [Adam.1993] tended toward linked manufacturing so that workpiece movements within batch production are performed flexible. The contribution on hand develops a new strategy to optimize identical manufacturing lines performing different types of manufacturing. The main components of the flexible manufacturing line are featured by working stations which are connected by intermediate buffers (see [Renn.1986]). Each working station comprises one or more working units (machines, labor).

Intermediate buffers serve as buffers accommodating one or more workpieces and/or workpiece carriers, just to bridge time. To arrange a manufacturing line, in most cases one or several of the following conventional structures are adopted (see [Kuhn.1998], [Salv.2001]):

- Stiff linkage of working stations (Fig. 1.a): which means a firm sequence of working stations where the workpieces are machined. Workpiece movement from one station to the next is limited by the state of following station, i.e. depends on its state (workpiece is still being machined, station is clear or failed).

- Loose and elastic linkage of working stations (Fig. 1.b): The stations are connected by buffers. The main goal of these buffers is to prevent waiting times for workpieces at a station and/or avoid blocking of a workpiece at the preceding station. Varying machining times between the stations are compensated by buffers.

- Branched (non-linear) linkage of working stations (Fig. 1.c): In this configuration, one buffer can be used by 
several stations, i.e. the buffer is provided as entrance buffer for many stations. Furthermore, multi-step buffering of one station or several stations can be performed. Figure 1.c shows the possibility of using a by-pass buffer (see [Furm.1992]) of linear or non-linear manufacturing lines.

(a)-

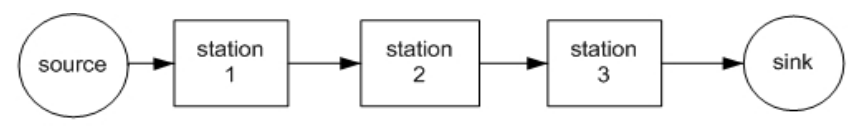

(b)-

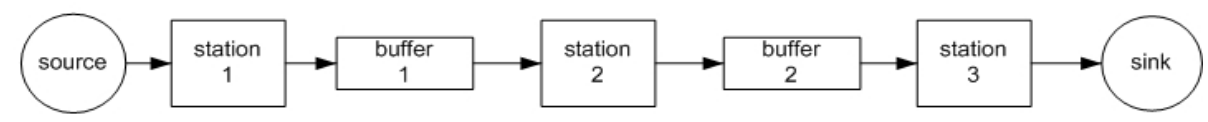

(c)-

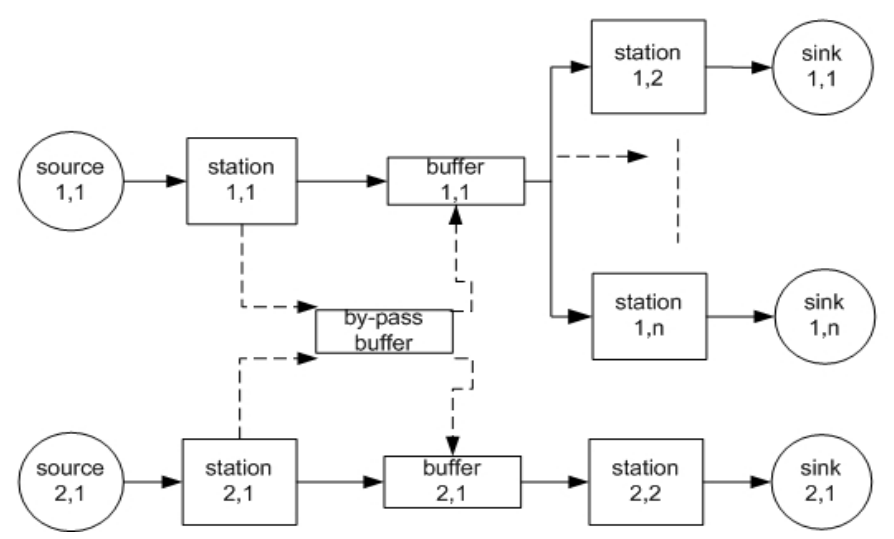

Fig. 1: Three conventional linkage configurations of working stations in manufacturing line

\section{Manufacturing lines combined by buffers}

Buffers in a manufacturing line provide compensation for differing machining times at successive stations: buffer may be arranged between two stations each, (Fig. 1.b) so that the component numbers of the manufacturing lines will double and capital outlay cost will increase. Considering several production lines producing equal products in a factory there is a demand for optimization of such lines and for reduction of costs. For this purpose, two lines are connected to each other by buffers. The following assumptions are made to prepare the new model:

- The two manufacturing lines are identical so that they feature equal components and conditions of use.

- The two lines execute similar orders so that equal products are being made.

To construct the new model, two side-by-side stations each of the two lines (symmetrical arrangement) are connected by a common exit buffer. The buffers available in one of the two lines are used as common exit buffers (Fig. 2). It is also possible to modify buffer capacities.

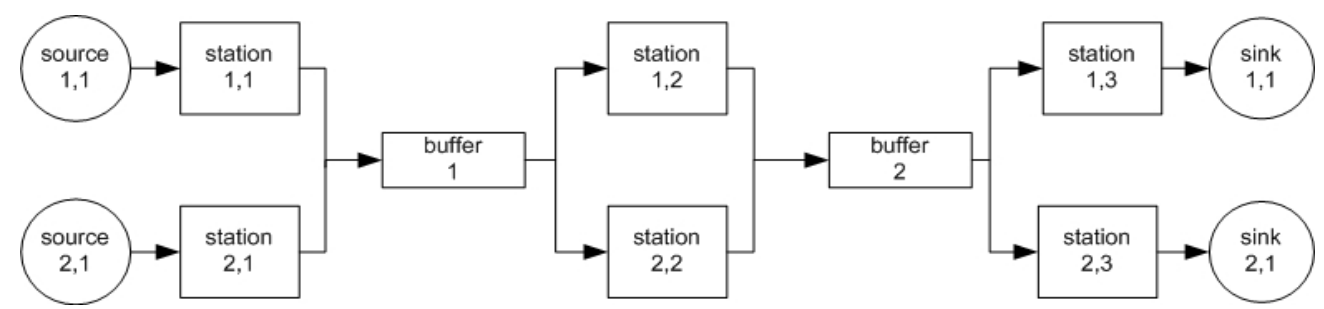

Fig. 2: The new combined configuration 


\section{Reducing the planned buffer capacities by half}

The goal to reduce the number of buffers by half does not necessarily means an increase in buffer capacities to maintain the output achieved before.

As long as the distribution of machining times at the two parallel working stations is not constant (e.g. general or Erlang distribution), the workpieces leaving the stations do not usually arrive at the common buffer at the same time. In an analogous way, they do not leave it simultaneously, either. Workpiece movements from the common buffer as well as to the common buffers depend on buffer capacities and on the distribution of the machining times to the stations which are connected with that buffer. Buffer capacities are calculated by adopting the analytical method and simulation. With the support of the analytical method some material flow systems can be investigated in order to calculate the mean buffer capacities due to a time period that is long enough, so good estimations for simple systems are possible. While simulation can emulate more complex real systems and determine optimal buffer capacities in limited desired time. The simulation model must represent the real systems exactly enough in order to be allowed to draw conclusions from the simulation experiments (cp. [VDI 3633]).

\subsection{1 Application analytical method}

Literature refers to a number of material flow systems analyzed by adopting the queueing theory, not only in the manufacturing sector and in logistics e.g. [Furm.1992] [Libe.2006] and [Gers.2003] but also in information technology, e.g. [Bolc.2006]. It is assumed that two identical manufacturing lines - as shown in Fig. 3 - are combined by a buffer and that the distribution of machining times of each of the working stations is general. Mean values, variances and coefficients of variations are the only parameters of this distribution which are known.

(a)
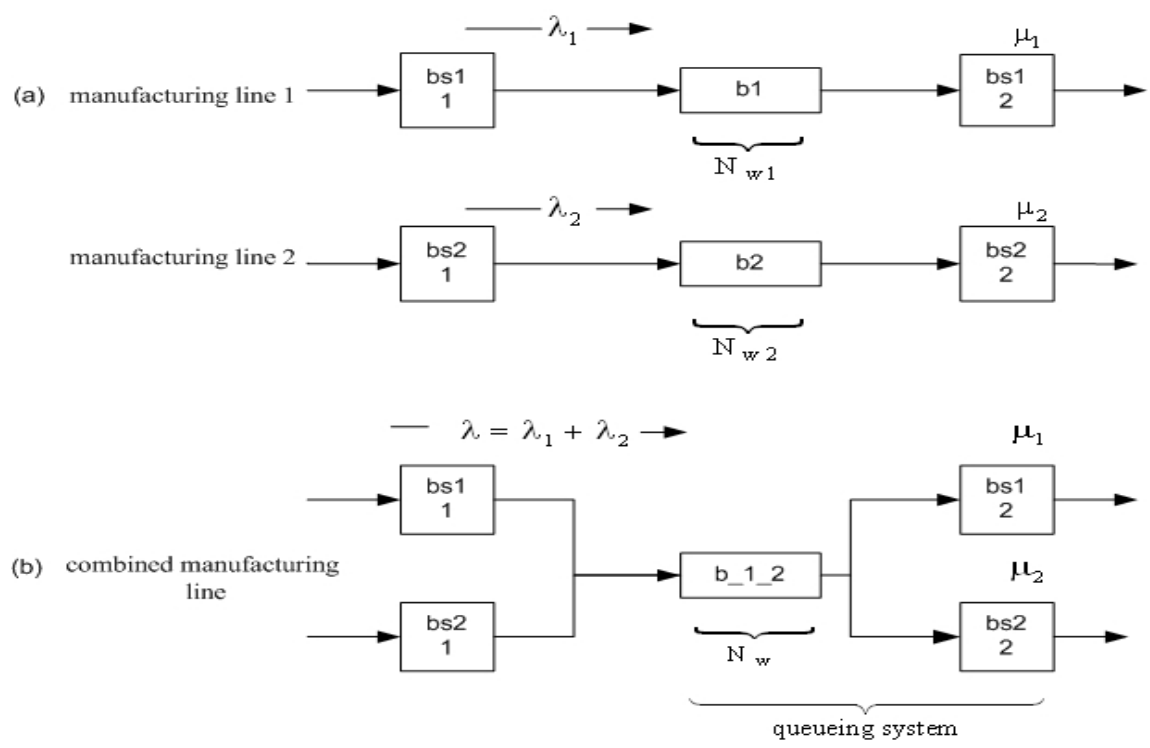

Fig. 3: Two identical manufacturing lines and their combined structure

Despite the practical importance of the use of $\mathrm{G} / \mathrm{G} / 1$ and $\mathrm{G} / \mathrm{G} / \mathrm{m}$ models in material flow systems, no definite formulae for the computation of their parameters are stated yet. To examine this model the following assumptions are made:

- $\lambda_{1}=\lambda_{2}$ : Arrival rate of workpieces in the buffers $(\mathrm{b} 1, \mathrm{~b} 2)$ [workpiece/unit of time]

- $\lambda=\lambda_{1}+\lambda_{2}$ : Arrival rate of workpieces in buffer (b_1_2)

- $\mu_{1}=\mu_{2}=\mu$ : Operation rate (service rate) of workpieces in the working stations (bs12, bs22) [workpiece/unit of time]

- $\mathrm{N}_{\mathrm{w} 1}, \mathrm{~N}_{\mathrm{w} 2}$ : Mean value buffer capacities (b1, b2) with waiting process in steady-state (cp. [Arno.2005])

- $\mathrm{N}_{\mathrm{w}}$ : mean value of buffer capacity (b_1_2)

- Buffer capacities are unlimited, i.e. there is still place for new workpieces

- Each manufacturing line in Fig. 3 is to be considered as $\mathrm{G} / \mathrm{G} / 1$ model. Analogously, the combined manufacturing line is to be considered as $\mathrm{G} / \mathrm{G} / \mathrm{m}$ model.

- $\quad \mathrm{m}=2$ : Number of working stations arranged after buffer (b_1_2) 
- $\mathrm{v}_{\mathrm{a}}=\frac{\sqrt{\operatorname{Var}\left(\mathrm{t}_{\mathrm{a}}\right)}}{\mathrm{E}\left(\mathrm{t}_{\mathrm{a}}\right)}$ (cp. [Arno.2005]): coefficient of variation of arrival processes; $\mathrm{E}\left(\mathrm{t}_{\mathrm{a}}\right)$ :mean value of machining time (service Time) of stations which are arranged before the buffer, $\operatorname{Var}\left(\mathrm{t}_{\mathrm{a}}\right)$ : variance of mean value

- $\mathrm{v}_{\mathrm{b}}=\frac{\sqrt{\operatorname{Var}\left(\mathrm{t}_{\mathrm{b}}\right)}}{\mathrm{E}\left(\mathrm{t}_{\mathrm{b}}\right)}$ : coefficients of variations of machining process (service process); $\mathrm{E}\left(\mathrm{t}_{\mathrm{b}}\right)$ : mean value of the machining time of stations which are arranged after the buffer, $\operatorname{Var}\left(\mathrm{t}_{\mathrm{b}}\right)$ : variance of mean value

With utilization rate $\left(\rho_{1}=\frac{\lambda_{1}}{\mu_{1}}<1\right.$ and $\left.\rho_{2}=\frac{\lambda_{2}}{\mu_{2}}<1\right)$ for the $\mathrm{G} / \mathrm{G} / 1$ model in Fig. 3.a, hence it follows that $\rho=\frac{\lambda_{1}+\lambda_{2}}{\mu_{1}+\mu_{2}}=\frac{\lambda}{2 \mu}<1$ in the $\mathrm{G} / \mathrm{G} / \mathrm{m}$-model, (Fig. 3.b) is also correct.

When the waiting process is stationary (steady state) and the number of workpiece $(K)$ in the queuing system $(k \geq$ $\mathrm{m})$, the rate of utilization is calculated according to [Arno.2005] and [Bolc.2006]: $\rho=\frac{\lambda}{\mathrm{m} \mu}$

Many approximations are mentioned by [Bolc.2006] to determine the mean waiting time of a workpiece ( $\overline{\mathrm{W}}$ ), e.g.: Approximation of Allen-Cunneen (A-C) formula:

$\overline{\mathrm{W}} \approx \frac{\mathrm{P}_{\mathrm{m}} / \mu}{1-\rho} \frac{\mathrm{v}_{\mathrm{a}}^{2}+\mathrm{v}_{\mathrm{b}}^{2}}{2 \mathrm{~m}} ; \mathrm{P}_{\mathrm{m}}$ : The probability that a workpiece cannot be machined immediately $(\mathrm{k}>\mathrm{m})$

Approximation of Krämer-Langenbach-Belz:

$\overline{\mathrm{W}} \approx \frac{\mathrm{P}_{\mathrm{m}} / \mu}{1-\rho} \frac{\mathrm{v}_{\mathrm{a}}^{2}+\mathrm{v}_{\mathrm{b}}^{2}}{2 \mathrm{~m}} \mathrm{G}_{\mathrm{KLB}}$

$\mathrm{G}_{\mathrm{KLB}}=\left\{\begin{array}{lr}\exp \left(-\frac{2}{3} \frac{1-\rho}{\left.\mathrm{P}_{\mathrm{m}} \frac{\left(1-\mathrm{v}_{\mathrm{a}}^{2}\right)^{2}}{\mathrm{v}_{\mathrm{a}}^{2}+\mathrm{v}_{\mathrm{b}}^{2}}\right),}\right. & 0 \leq \mathrm{v}_{\mathrm{a}} \leq 1, \\ \exp \left(-(1-\rho) \frac{\mathrm{v}_{\mathrm{a}}^{2}-1}{\mathrm{v}_{\mathrm{a}}^{2}+4 \mathrm{v}_{\mathrm{b}}^{2}}\right), & \mathrm{v}_{\mathrm{a}}>1\end{array}\right.$

The calculation of $\mathrm{N}_{\mathrm{w}}$ can be performed on the basis of Little's Law: $\mathrm{N}_{\mathrm{w}}=\lambda \overline{\mathrm{w}}$

To determine the saving of buffer capacity in the combined manufacturing line the values $\left(\mathrm{N}_{\mathrm{w}}\right)$ in specific cases $(\mathrm{m}$ $=1$ and $\mathrm{m}=2$ ) will be calculated and compared with each other.

On the basis of [Bolc.2006], diagram 1 is as shown below. This diagram shows that the higher the value (m), the higher is the saving of buffer capacity, when the utilization $\rho$ is constant $(\rho=\rho 1=\rho 2)$. The mean value of buffer capacity in the combined manufacturing line can be reduced by more than half.

\subsection{Applying simulation}

With the aid of simulation, real conditions can be reproduced and sufficient details visualized. It is assumed that buffer capacities (Fig. 4) are limited. If the machining times of two successive stations are almost identical (identical mean value and different deviation), so the combined structure of a manufacturing lines provide a significant $50 \%$ reduction of the buffer capacities planned.

Example: It is assumed that the mean value of the machining times at station A, C, D, L, M, N, A1, C1, D1, L1, M1 and N1 in Fig. 4 is 30 seconds Erlang distributed, 10 seconds standard variation, lower limit 20 seconds and upper limit 40 seconds. The capacities planned for two symmetrical buffers each (b2, b5 and b3, b6) in two conventional manufacturing lines mean 10 storage locations totalling to 20 storage locations per manufacturing line. These buffer capacities were chosen according to the diagrams 2 and 3 so that an as large as possible throughput in consideration of the increasing of buffer utilization (cp. diagram 4) and thus a reduction in buffer costs are achievable. If the capacity of common buffers ( $\mathrm{P}_{2} 2$ 5, $\left.\mathrm{P} \_3 \_6\right)$ in a combined structure comprises 10 storage locations, an almost identical throughput is achieved as compared to the conventional structure. The times to be spent in buffers (machining time, recovering time or cycle time) have been considered to be negligible. 


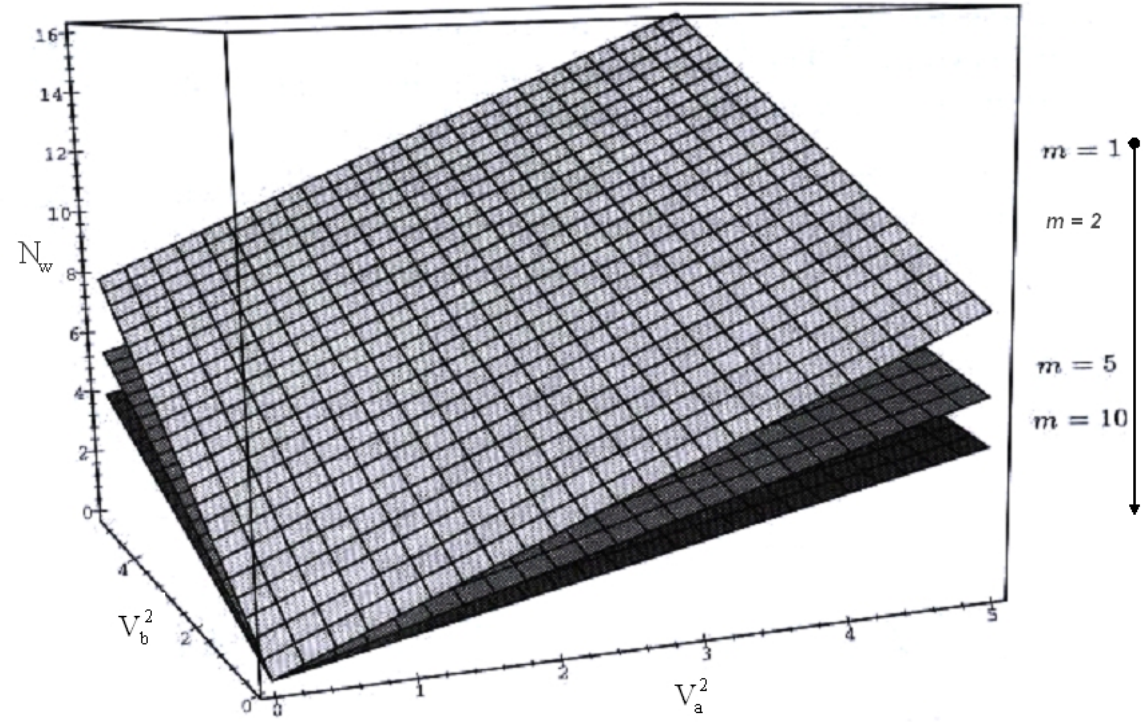

Diagram 1: The mean value of the number of workpieces $\left(N_{w}\right)$ for the $G / G / m$ model (with $\rho=0.8$ ) on the basis of [Bolc.2006]

Diagrams 2 and 3 illustrate the following:

- With increased buffer capacities in a manufacturing line throughput increases, too.

- However, there is an optimal buffer capacity so that a further increase in capacity would produce no or only a small negligible improvement of throughput.

- As regards the new structure, the buffer capacities are to be reduced by half.

The combination results in a higher flexibility for the supply of the following processes from preceding processes in both manufacturing lines. By use of smaller required buffer capacities this flexibility leads to the decrease of time losses. The diagram 4 illustrates a probability of frequencies of the contents of the last buffers (P2, P5 and P_2_5) optimized in the three different manufacturing lines which have been shown in Fig. 4.

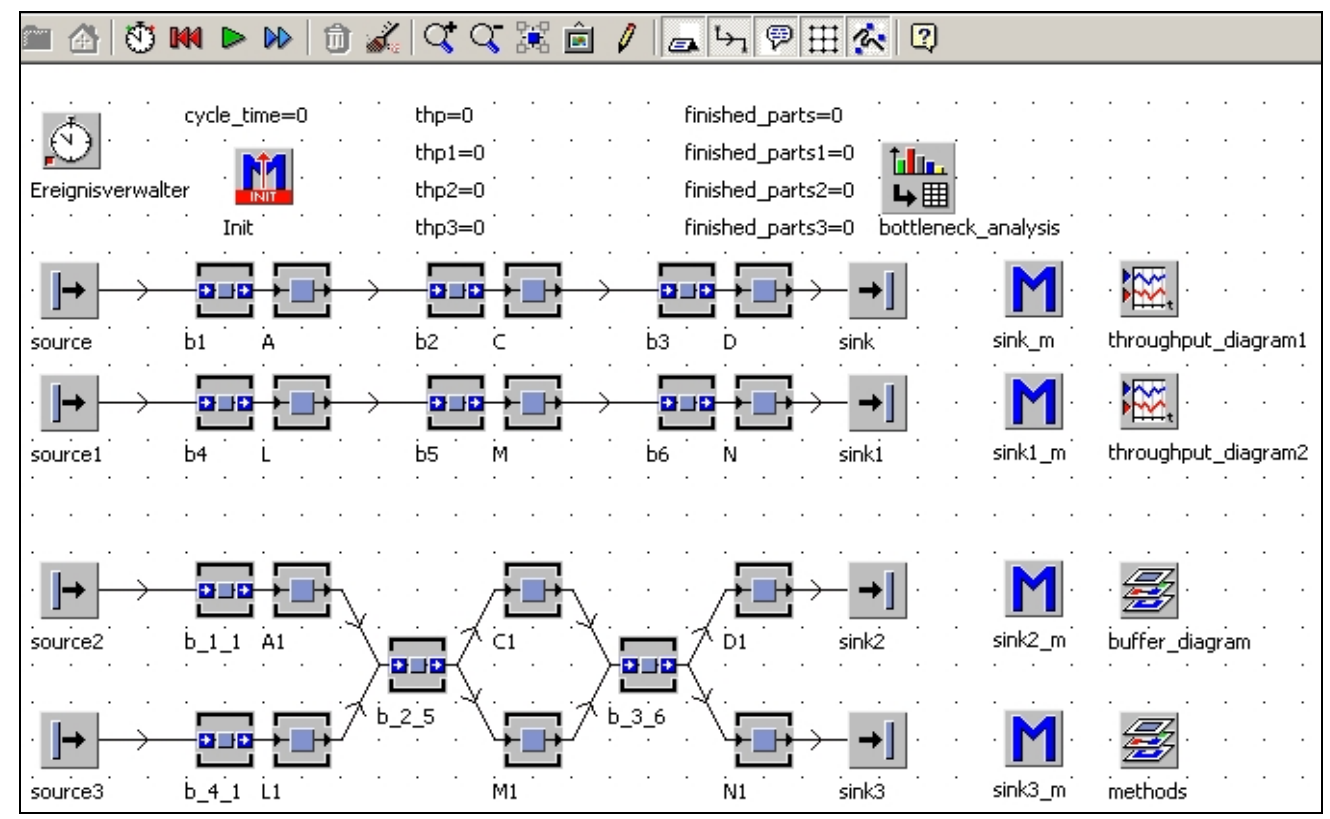

Fig. 4: Two simulated manufacturing lines and their combined structure. thp and thp1 represent throughputs [pieces/hour] at the exits of the conventional manufacturing lines; thp2 and thp3 are the throughputs at the exits of combined manufacturing lines. 


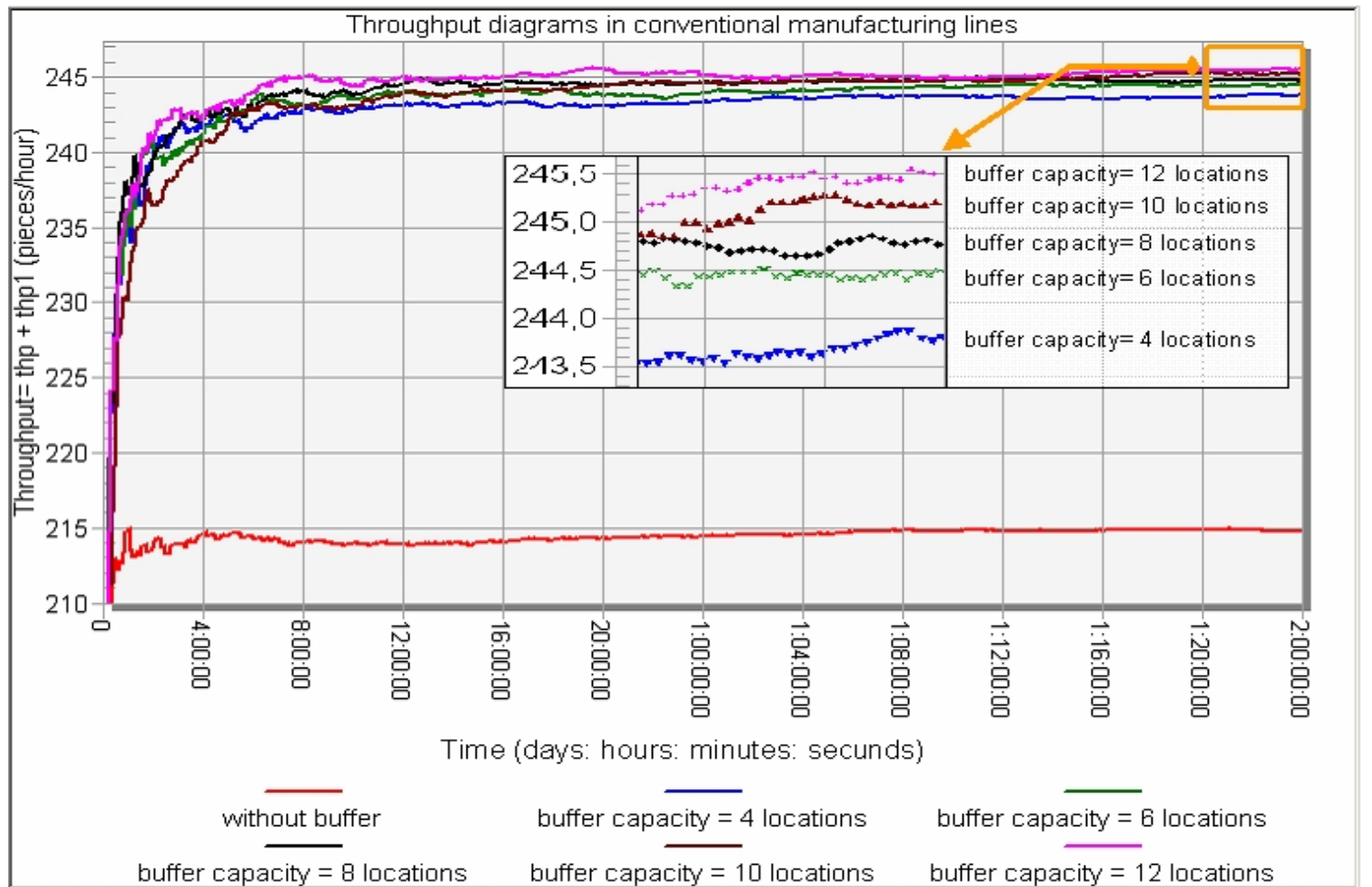

Diagram 2: The correlation between buffer capacities and achievable throughputs in conventional manufacturing lines. Testing period amounts to 48 hours ( 2 days).

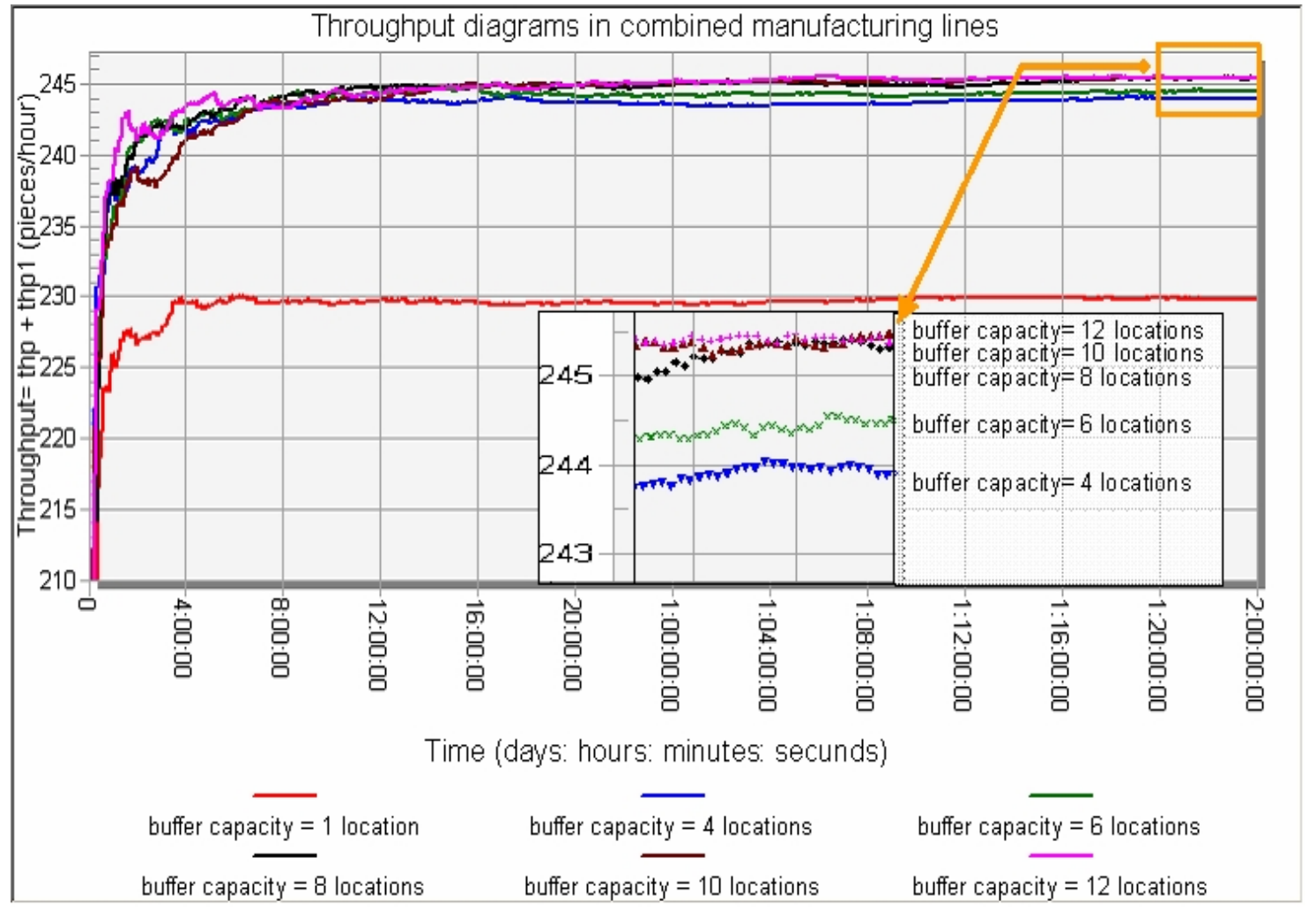

Diagram 3: The correlation between buffer capacities and achievable throughputs in combined manufacturing lines. Testing period amounts to 48 hours (2 days). 


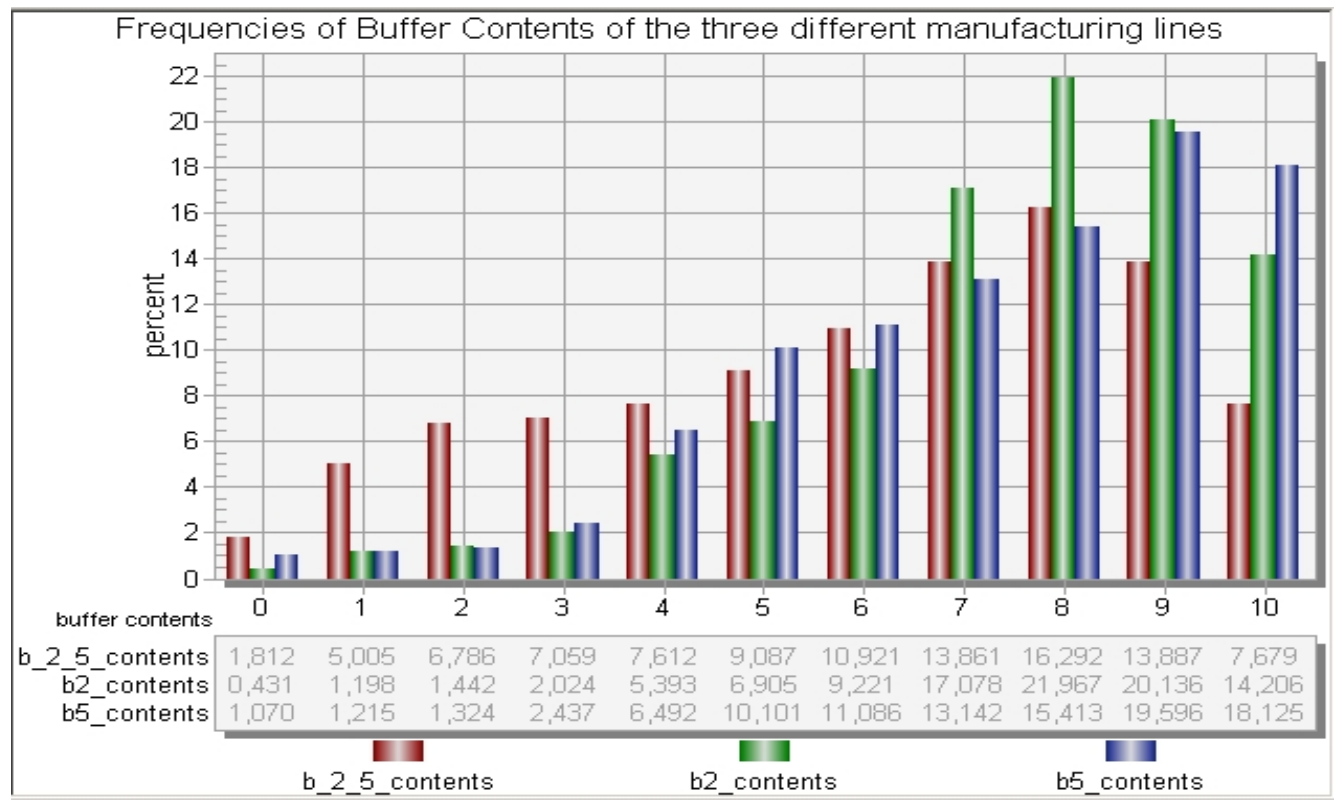

Diagram 4: Probable frequencies of contents in buffers (P2, P5 and P_2_5) in the three different manufacturing lines of Fig. 4. Testing period is 48 hours (2 days).

\section{Reduction of space required}

The new structure provides that the areas of buffers which are no longer necessary, hence the areas for these buffers previously arranged in-between the manufacturing line are gained. The larger the difference between the machining times, the larger the buffer capacity to be provided. This increase in buffer capacity is necessary to increase the rate of utilization of working stations by reducing the blocking times and finally to increase throughput. As for example, vertical buffers are available as an economic solution in combined manufacturing lines.

\section{Further increase of throughput}

As each entrance buffer in the combined manufacturing line is fed by two stations, the waiting time at the following stations is reduced which results in an increase of throughput, but this possibility diminishes when the capacity of the common buffer is limited so that the blocking time increases due to the fact that buffers are charged to capacity.

However, in specific cases, significant increase in throughput can be obtained. If the machining time of a station in Fig. 1,b is longer than the machining time of the immediately preceding station, but smaller than double so that adding of a parallel identical station for increased throughput is inefficient, the new structure offers the possibility of adding a parallel station to the two symmetrical stations.

Example: On the assumption that the mean value of the machining times at stations A, L, A1 and L1 in Fig. 5 is 20 seconds and those of stations C, M, C1, M1 and C2 30 seconds (Erlang distribution), the throughput of the combined manufacturing line as a whole may efficiently increase by max. $30 \%$ (see diagram 5 ).

\section{Reduction of failure effects consequences}

In this new configuration, two parallel stations each are supplied with workpieces by one input buffer and the finished workpieces are supplied to an exit buffer so that there are no direct connections between the stations (cp. fig 2). If failure occurs at a station, so its effect on the manufacturing line will be relatively small as the following stations will be fed by a common input buffer and simultaneously the upstream stations will be disposed of workpieces in the relevant common exit buffer. Furthermore, in most cases the capacity of the common buffer (e.g. b_2_5) (see Fig. 4) can be dimensioned to be bigger than the capacities of the respective buffers (b2, b5). 


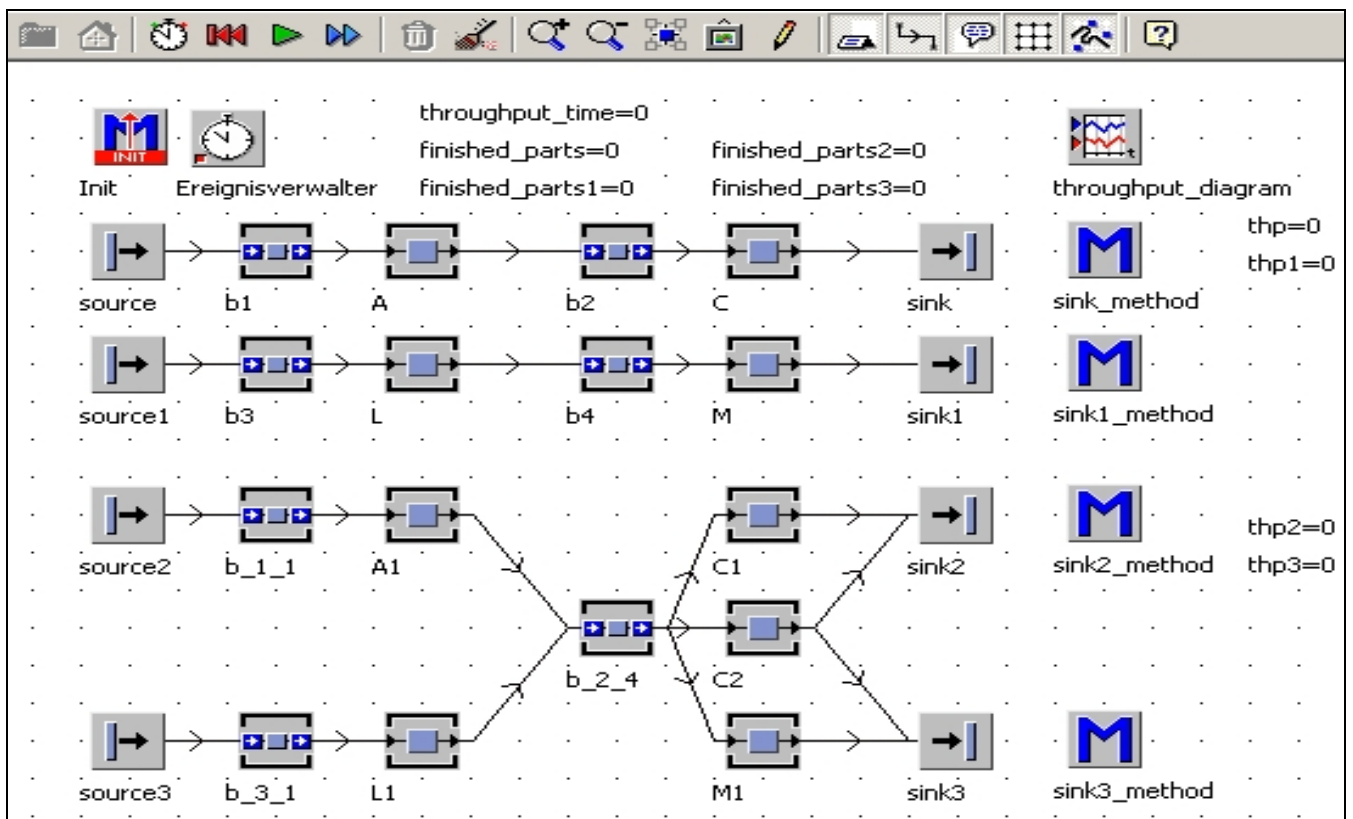

Fig. 5: Possibility of adding another parallel station to the two parallel stations

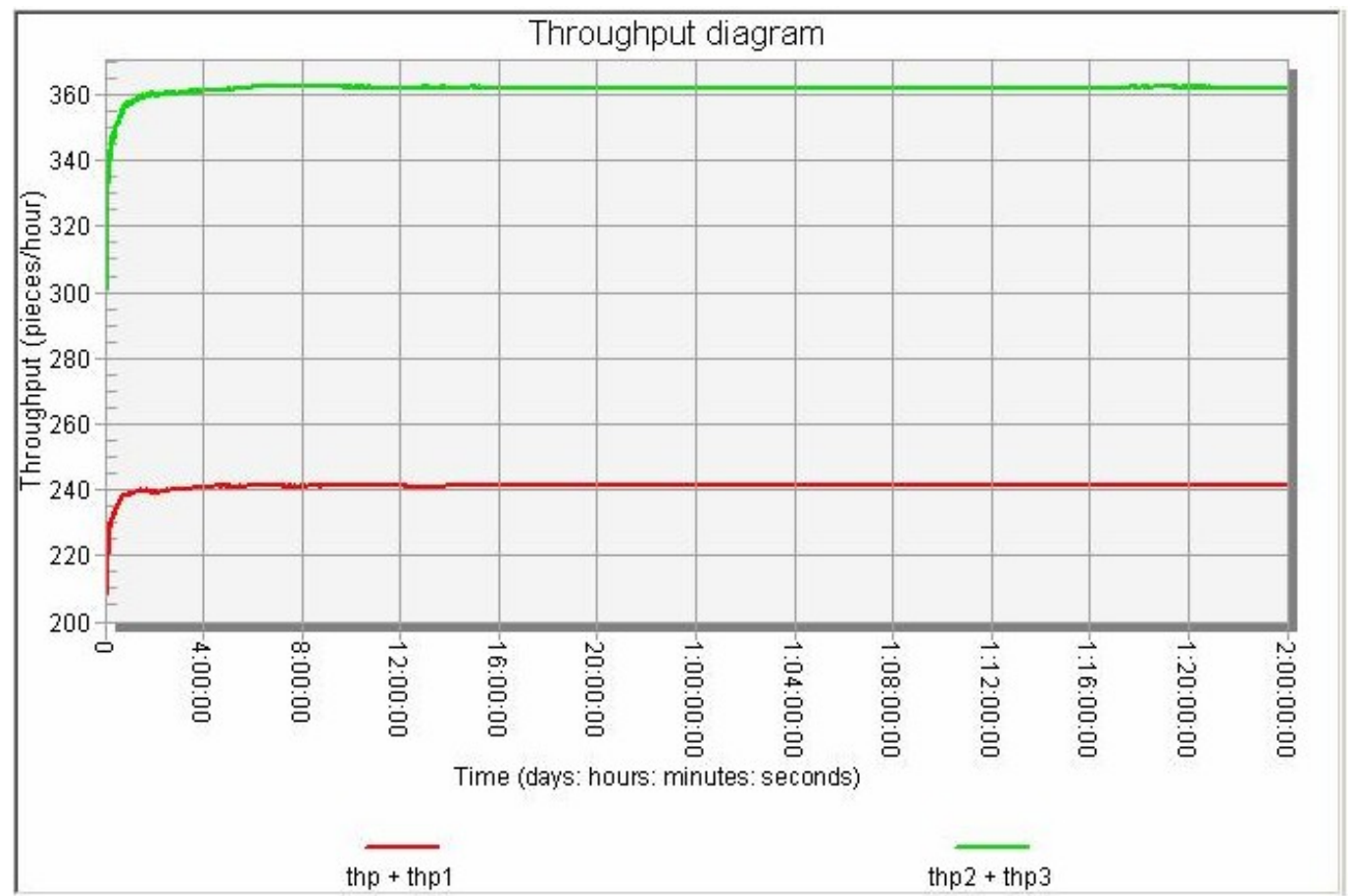

Diagram 5: Possibility of efficiently increasing the throughput. The test period is 48 hours (2 days).

Generally, the effects of failures depend on the duration of failures, on the capacities of input and exit buffers of the stations and on arrival and service rate.

\section{Further potentials can be as follows:}

Initially, the new model ensures optimization of identical manufacturing lines so that their performances increase while capital expenditure reduces. Finally, it becomes possible to apply this structure for non-identical manufacturing lines and flow assembly so that buffers with increased capacities or decentral storages are used as common buffer. So every buffer location can be allocated from each of the different products.

The flow of products does not change and stays as it was before the combination of the single buffers. This means that a determined product in individual case must be only conveyed to a determined station (due to work plan). This includes the following advantages:

- Considerable saving of space required of buffers due to increase of buffer utilization.

- Possible using of storage techniques. 


\section{Literatur}

[Adam.1993]

[Arno.2005]

[Bolc.2006]

[Furm.1992]

[Gers.2003]

[Kuhn.1998]

[Libe.2006]

[Renn.1986]

[Salv.2001]

[Tuff.1988]

[VDI 3633]
Adam, Dietrich: Flexible Fertigungssysteme: Flexible Fertigungssysteme (FFS) im Spannungsfeld zwischen Rationalisierung, Flexibilisierung und veränderten Fertigungsstrukturen. Wiesbaden: Gabler, 1993. ISBN: 3-409-17914-3

Arnold, Dieter; Furmans, Kai: Materialfluss in Logistiksystemen (4. Auflage). Springer Berlin Heidelberg New York: 2005. ISBN: 3-540-22800-4

Bolch, Gunter; Greiner, Stefan; de Meer, Hermann; S.Trivedi, Kishor: Queueing networks and Markov Chains: Modeling and performance evaluation with computer science applications. Hoboken, NJ : Wiley-Interscience, 2006. ISBN-13 978-0-471-56525-3, ISBN-10 0-471-56525-3.

Furmans, Kai: Ein Beitrag zur Theoretischen Behandlung von Materialflusspuffern in Bediensystemnetzwerken. Karlsruhe: Inst. für Fördertechnik, 1992. ISSN 171-2772. B.Gershwin, Stanley; Dallery, Yves; T. Papadopoulos, Chrissoleon; Smith., J.MacGregor: Analysis and modeling of manufacturing systems. Boston [u.a.] : Kluwer Acad. Publ., c 2003. ISBN: 1-4020-7303-8.

Kuhn, Heinrich: Fließproduktionssysteme: Leistungsbewertung, Konfigurations- und Instandhaltungsplanung. Heidelberg : Physica-Verl., 1998. ISBN: 3-7908-1128-9. Liberopoulos, George; Gershwin, Stanley B. ; Papadopoulos, Chrissoleon T. ; Smith, J. M. ; Tan, Baris: Stochastic modeling of manufacturing systems : advances in design, performance evaluation, and control issues. Berlin, Heidelberg : Springer-Verlag Berlin Heidelberg, 2006. ISBN: 3-540-26579-1, 978-3-540-26579-5.

Renn, Werner: Struktur und Aufbau Prozeßnaher Steuergeräte zur Verkettung in flexiblen Fertigungssystemen. Berlin [u.a.]: Springer, 1986. ISSN 3-540-16150-3, 0-38716150-3.

Salvendy, Gavriel: Handbook of industrial engineering: Technology and operations management. New York, NY [u.a.] : Wiley, 2001. ISBN: 0-471-33057-4.

Tuffentsammer, Karl; Storr, Alfred; Pritschow, Günter; Warnecke, Hans-Jürgen: Flexibles Fertigungssystem: Beiträge zur Entwicklung des Produktionsprinzips. Weinheim [u.a.] : VCH, 1988. ISBN: 3-527-27706-4.

Simulation von Logistik-, Materialfluß- und Produktionssystemen. Düsseldorf: VDIVerl., 1993 